\title{
ANTWOORD OP DEIST SE KRITIEK
}

F. N. Lion-Cachet.

"Dit is baie maklik om 'n pop, na jou eie inbeelding gemaak, op te stel, en dit dan met klippe onderstebo te gooi. Maar is dit wetenskaplik?"

Totius.

F. E. Deist (Des. 1984: 47-56) het in sy reaksie op my kritiek op ' $n$ ABC van Bybeluitleg (Maart 1984:38-51) geoordeel dat ons verskille op kenteoretiese vlak lê en sy hele diskussie daarvolgens gevoer. Hy het my nie t.o.v. my kernkritiek op die $\mathrm{ABC}$ geantwoord nie maar "my kenteorie" (waaroor dit nie in my kritiek gegaan het nie) as Platonies-realisties (Neoplatonies) gebrandmerk en aan homself ' $n$ histories-kritiese kenteorie in die tradisie van (Vico, Spengler), Collingwood en Popper toegeëien. Na 'n paar inleidende vraagtekens, wat ek weer kan bevraagteken, het hy tot die aanval oorgegaan. Aanval is mos die beste verdediging. Hy soek dan na voorbeelde van my "Platoniese kenteorie" en nooi my dan uit om op kenteoretiese vlak verder met hom die gesprek te voer.

Ek het weinig smaak vir 'n filosofies-kenteoretiese gesprek, maar ek is van oordeel dat ons verskil van uitgangspunt op hermeneutiese sowel as op kenteoretiese vlak gou duidelik sal word, want dit is ten diepste dieselfde.

\section{'N NEOPLATONIS?}

Ek wil dit ten eerste duidelik stel dat ek met die Neoplatonistiese en die histories-kritiese kenteoretiese metodes geen simpatie het nie. Ek voel my meer tuis in die geselskap van Van Til. Van Til $(1969: 1)$ het die Christelike epistemologie as 'n openbaringsepistemologie ("revelational epistemology") beskrywe. Hy stel dat ware menslike kennis ooreenstem ("corresponds") met die kennis wat God van Homself en van hierdie wêreld het. Ek sou dit net duidelikheidshalwe wou stel dat dit die kennis is wat God aan ons geopenbaar het. Ons bekom van God (en die wêreld) ektipiese en nie argetipiese kennis nie (cf. Bavinck $191811: 90$ ).

Met bogenoemde wil ek heel eenvoudig stel dat ek in die her. meneuse sowel as in die kenteoretiese wetenskap met die erkenning van God wat Homself gesagvol en onfeilbaar in sy Woord openbaar het, wil begin. Hierdie beginpunt soek ek in die redelike getuienis van die Skrif want "uit Hom en deur Hom en tot Hom is alle dinge" (Rm. $11: 36$ ). Aan die ander kant is daar soveel filosowe met 'n groot verskeidenheid waarheidsteorieë (cf. Van der Merwe 1958: 88) en meeste van hulle fundeer hulle teorieë irrasioneel. D wil hom graag in die geselskap van Collingwood en Popper bevind. Dit is natuurlik sy reg om saam met hulle vanuit 'n sekere uitgangspunt te redeneer. Ek veronderstel dat hy nie met alles wat hulle sê sal saamstem nie en dit is daarom vir my moeilik om te reageer op sy eie standpunt. Ek gaan seker nie te ver as ek egter wil beweer dat die 
histories-kritiese kenteoretiese uitgangspunt rasioneel gefundeer is nie. Visagie $(1983: 1)$ het o.a. veel vraagtekens agter Popper se eerbied vir sy s.g. Objektiewe Kennis gestel, terwyl Popper self toegee dat die grondliggende keuse vir rasionaliteit self irrasioneel is. As D se uitgangspunt inderdaad rasioneel is, is dit duidelik dat die verskil tussen ons dieper as 'n kenteoretiese verskil is. Dit is 'n verskil in uitgangspunte.

\section{MISTASTINGE}

'n Groot deel van D se kritiek is 'n poging om aan te toon dat ek my aan 'n soort Platoriese idealisme skuldig maak. 'n Paar opmerkinge hieroor sal gepas wees.

Ek poneer dan dat daar ' $n$ algemene of universele gehoor sou wees $(1984: 48)$. Dit is dan 'n kenteoretiese veronderstelling. Ek was natuurlik nie op daardie stadium met 'n uiteensetting van 'n moontlike eksegetiese metode besig nie en het die begrip nie uitgebrei nie. D het egter goed begryp waarom dit gaan maar hy het die klem net anders gelê as wat baie ander dit sou gedoen het. Vanuit die uitgangspunt dat God, die Spreker, in sy openbaring in die ou bedeling ook vir die mens van alle tye (die universele gehoor) 'n boodskap het, het ek probeer om te sê dat "die hele Skrif nuttig is ... sodat die mens van God volkome kan wees" (cf. 2 Tim. 3:16). D maak dan 'n sprong deur 'n begrip "ideële gehoor", waaraan ek dan soveel waarde sou heg, by die hare in te sleep. Hy smeer ook die begrip "ideële "kerk" op my brood. Dit pas natuurlik by sy Platoniese "idee", waarvan hy my beskuldig, in. Maar ek het die begrip nie gebruik nie en wou dit nie gebruik nie. Ek bedoel dit ook nie.

D (1984:49) meen ek is op soek na bowe-historiese, univcrseclgeldende kontinuums; hy meen dat ek die "historiese" vermy en van God (die Neoplatoniese EEN) na die wêreld van die verskynsels (via die nous en die psyche) terugredeneer en so die Bybel as 'n "emanasie" van God maak. Hy is egter reg as hy beweer dat ek min van hierdie aantygings sal toegee. Die toedigsels bly my vreemd. As hy my wil aanspreek sal dit op 'n ander vlak moet wees. Ek het 'n openbarings-historiese uitgangspunt en mak van 'n gramatieshistoriese metode gebruik om die Woord wat deur God se besondere sorg aan ons oorgelewer is (cf. 2 Pt. 1:19-21) te verklaar.

Ek word verder van 'n meganiese inspirasiebegrip verdink (1984:50), wat ek volgens hom nie sal aanvaar nie. Ek het inderdaad Schulze se aanhaling: "Hiertoe het die Gees die Bybelse getuies selfs in hulle woordkeuse gelei", met instemming gebruik. Schulze het in sy artikel, waaruit ek die aanhaling gemaak het, Calvyn en die Skrifgesag bespreek. Calvyn was ook al van 'n meganiese inspirasieleer beskuldig! Ek is oortuig dat nog Calvyn, nog Schulze of ekself ' $n$ meganiese inspirasieleer huldig maar dat die misterie van die Skrifinspirasie moeilik te omskrywe is en dat Schulze (1980: 32) deur die bepaalde uitspraak wou stel dat vorm en inhoud volgens Calvyn nie so maklik onderskei (of selfs geskei) kan word as wat die liberale teoloë sedert Semmler geglo het nie. 
D (1984: 51) beskuldig my verder van 'n onhistoriese of selfs 'n a-historiese, benadering soos dit dan uit my opmerkings t.o.v. die rabbynse uitlegmetodes, blyk. Ek was weereens nie besig om 'n eksegetiese metode uiteen te sit nie, maar om aan te toon dat daar onder die eksegete wat histories-letterlik te werk gaan, ook diegene is wat literêre beoordeling en historiese konteks in ag neem. Persoonlik oordeel ek dat 'n eksegeet nie sonder literêre beoordeling, kultuurhistoriese kennis en implimentering daarvan en die openbaringsbetekenis van ' $n$ bepaalde teksgedeelte, soos dit in die lig van die hele Skrifopenbaring na vore kom, tot 'n geldende verklaring kan kom nie.

As die "onhistoriese rabbynse metodes" (D 1984:51) vir my meer as die histories-kritiese metodes aanvaarbaar is, is dit 'n speelse keuse tussen twee metodes wat ek nooit vandag sou wou gebruik nie. Ek sal my egter weerhou om die rabbynse metodes soos dit deur die Bybelskrywer gebruik was, te gekorrigeer. Hulle het van die beste metodes van hulle tyd gebruik gemaak. En "Hoewel Paulus in baie opsigte dieselfde metode van Skrifverklaring gebruik as die rabbyne en die manne van die Qumran-gemeenskap, kom hy tot 'n volkome ander vertolking van die Skrif... Die Damaskus-gebeure het ' $n$ ingrypende verandering in Paulus se lewe en ook in sy manier van Skrifvertolking veroorsaak." (Floor 1981:56). Ek buig steeds onder die besef dat die Heilige Gees die skrywers van die Skrif met hulle "swakke" metodes tog die waarheid laat verkondig het. Die Skrif is nie die produk var menslike wysheid nie, maar die openbaring van God (2 Pt. $1: 21)$

\section{'N LOS OPMERKING}

Ek onderdruk die begeerte om puntsgewys op elke kritiekpunt en uitspraak te reageer. Die moontlikheid dat ons mekaar verkeerd wil verstaan is so groot. Maar vergeef my hierdie een los opmerking. D (1984:47) het 'n aantekening gemaak by my woorde "'n Suiwer kennis van wie God en wat die Bybel is, is dus 'n belangrike vereiste." Hy mak eers van my "vereiste" 'n "voorvereiste" en dan berispe hy my met 'n beroep op art 1 NGB, dat alles tog maar "ten dele" is. Ek kan heeltemal verstaan wat hy vir my wil sê maar ek het dit nie in absolute sin bedoel nie. Ek het dit maar net bedoel soos dit in art. 29 NGB staan waar die merktekens van die ware kerk o.a. die "suiwer prediking van die evangelie" is.

Ander opmerkings laat ek daar.

\section{TEN SLOTTE}

Ek het steeds probleme met sy soeke na "onveranderlike konstantes" (1984: 49). Dit lyk vir my na 'n contradictio in terminus. Wat bedoel hy? Is die Bybelwaarheid relatief, aanpasbaar, en lei dit tot 'n nimmereindigende worsteling om begrip? Dit is waar ons verskil. Die Bybel is vir D "'n getuienisboek waarin die geloofsoortuiging en geloofsuitinge van meer as duisend jaar opgeteken is, duisend jaar waarin alles nie maar konstant gebly het nie, maar sienings van en 
oor God verander het,..." (Deist $1982: 23$ ). Dit lyk vir my of die Bybel vir D 'n menslike boek oor God is en ek bely dat die Bybel God se boek vir die mense is.

Bavinck, H. 1918. Gereformeerde Dogmatiek, II. Kampen: Kok.

Deist, F. E. 1982. Se God so? Kaapstad: Tafelberg.

Deist, F. E. 1984. 'n Kritiese evaluering van die kritiek van F. N. Lion-Cachet. In die Skriflig. 18/72: 47-56. Desember 1984.

Floor, L. 1981. Esegese en prediking by Paulus. In: Van't Spijker (R). Uw Knecht hoort.

Lion-Cachet, F, N. 1984. 'n Kritiese beskouing van Deist se "ABC van Bybeluitleg". In die Skriflig. 18/69: 38-51. Maart 1984.

Schulze, L. F. 1980. Calvyn en die Skrifgesag. In die Skriflig 14/56:27-39.

Van der Merwe, N. T. 1958. Op weg na 'n Christelike logika. Potchefstroom: Ongepubliseerd.

Van Til, C. 1969. In defense of faith, II. A survey of Christian epistemology. Dulk Christian Foundation.

Visagie, P. J. 1983. Aspekte van Popper se Wetenskapsleer. Potchefstroom. Dept. Wetenskapsleer, P.U. vir C.H.O. 